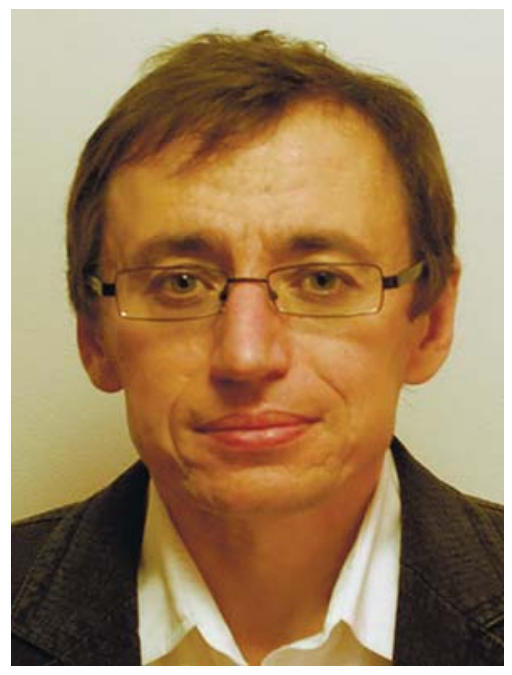

КОРДЮК

Олександр Анатолійович академік НАН України, директор Державної наукової установи «Київський академічний університет»

\section{ДЕРЖАВНА НАУКОВА УСТАНОВА «КИЇВСЬКИЙ АКАДЕМІЧНИЙ УНІВЕРСИТЕТ»: ІСТОРІЯ I НАПРЯМИ РОЗВИТКУ}

\author{
Шановний Анатолію Глібовичу! \\ Шановні колеги! \\ Дозвольте мені коротко розповісти про діяльність Державної
} наукової установи «Київський академічний університет». Хочу звернути вашу увагу, що, як і відображено у назві, це - саме наукова установа, а не заклад вищої освіти. У наших установчих документах записано, що основним завданням Київського академічного університету є «проведення фундаментальних та прикладних наукових досліджень», але водночас і здійснення «інноваційної освітньої діяльності за різними ступенями вищої освіти». І це відповідає суті концепції КАУ, в основу розвитку якого ми закладаємо два основні принципи: «наука через освіту» $\mathrm{i}$ «освіта через науку». Ці два принципи ми поєднали у короткій формулі: «Навчання через дослідження світового рівня», або англійською «Learning by doing research internationally». Мета такого навчання полягає в тому, щоб навчити студентів вирішувати наукові задачі, а також, що, мабуть, найголовніше, ці задачі ставити.

Київський академічний університет має подвійне підпорядкування - Національній академії наук України і Міністерству освіти і науки України. 3 одного боку, це дає нам можливість залучати найактивніших провідних учених Академії до викладання, наукового керівництва роботами студентів, залучення молоді до виконання реальних наукових проєктів за актуальними сьогодні у світі напрямами. 3 іншого боку, для $\mathrm{MOH}$ України КАУ - це пілотний проєкт, можливість відпрацювати в умовах України на прикладі невеличкого закладу структуру та принципи, закладені в найкращих дослідницьких університетах світу.

Основний принцип КАУ - навчання через дослідження реалізується через ретельний відбір обдарованих і схильних 
до творчої роботи студентів; індивідуальний підхід до кожного з них; залучення студентів буквально з перших кроків до наукових досліджень світового рівня; залучення до навчального процесу провідних науковців НАН України та потенціалу найкращих академічних лабораторій; максимальну інтеграцію у міжнародний науково-дослідницький простір.

Останнє дуже важливо, оскільки інтеграція до європейського і світового дослідницького простору неминуча, і лише розвиток та поглиблення міжнародної співпраці може загальмувати негативну тенденцію останніх десятиліть з відпливу талановитих молодих дослідників. Молодь прагне брати участь у міжнародних проєктах, працювати у провідних наукових центрах світу, це їх мотивує і надихає. Однак для того, щоб висококваліфіковані кадри не від'їжджали назавжди, це має бути не одноразова подія, а стале міжнародне співробітництво на постійній основі, тому цей напрям є одним 3 ключових компонентів у нашій діяльності.

Особливість і незвичність нашого дослідницького університету тісно пов'язана з його історією, яка починається з Київського відділення Московського фізико-технічного інституту (КВ МФТІ), створеного в 1978 р. за ініціативою Бориса Євгеновича Патона. Основним реалізатором цієї ідеї був Валентин Тихонович Черепін.

У Радянському Союзі МФТІ славився саме тим, що це був справжній дослідницький університет, у якому готували прикладних фізиків, які вміли вирішувати задачі. Практично всі викладачі в ньому були сумісниками, основним місцем роботи яких були науково-дослідні інститути. Вони відривалися від своїх цікавих досліджень на проведення лекцій та семінарів, і студенти безпосередньо, «3 перших рук», відчували, що таке «жива» наука. Тому студентам було цікаво, вони намагалися якомога раніше долучитися до реальних досліджень, і це їх мотивувало до кращого навчання.

МФТІ як магнітом притягував найкращих учнів з усього Союзу, і українська Академія, очевидно, відчувала це «вимивання мізків». I, власне, створення Київського відділення, студенти якого протягом 4 років отримували якісну освіту в МФТІ, а потім поверталися в Україну, в «базові» академічні інститути, стало геніальним вирішенням Борисом Свгеновичем цієї проблеми.

У 1997 р. КВ МФТІ було реорганізовано у Фізико-технічний навчально-науковий центр (ФТННЦ) НАН України, а у 2017-2019 рр. ФТННЦ реформовано в Київський академічний університет, одним з найактивніших ініціаторів створення якого був Анатолій Глібович Загородній.

За час існування Київського відділення було випущено більше 1 тис. студентів. Я також один з його випускників. Але основним здобутком можна вважати досвід дослідницького навчання, накопичений і студентами, і викладачами «базових» інститутів. I цей досвід дає нам впевненість, що ми знаємо, як потрібно будувати дослідницький університет, розуміємо основні принципи його устрою, маємо багато know-how, які забезпечують ефективність його функціонування, а також усвідомлюємо, що ці принципи та know-how слід постійно вдосконалювати й переглядати.

Тому процес реформування, початком якого можна вважати 14 грудня 2016 р., коли було підписано розпорядження Кабінету Міністрів України № 962-р «Про утворення державної наукової установи «Київський академічний університет»», тривав понад два роки. Однак за цей час ми не лише розробили концепцію розвитку КАУ в сучасних умовах, ліцензували та акредитували нашу освітню діяльність, а й зробили внесок у поліпшення законодавчої бази для функціонування дослідницьких університетів в Україні. Зокрема, вдалося внести зміни до згаданого вище розпорядження Кабінету Міністрів України, які закріпили положення про те, що КАУ «може залучати до освітньої та освітньо-наукової діяльності працівників науково-дослідних інститутів та інших установ Національної академії наук як науково-педагогічних або наукових працівників, що працюють у державній науковій установі «Київський академічний університет» за основним місцем роботи». Ця законодавча

ISSN 1027-3239. Visn. Nac. Acad. Nauk Ukr. 2021. (6) 
норма значно спрощує роботу дослідницького університету, всі лектори-викладачі якого працюють в академічних інститутах.

Я вже говорив про особливості нашого університету, додам лише, що весь освітній процес у КАУ підпорядкований науковій роботі. Наші студенти, порівняно зі студентами інших українських закладів вищої освіти, мають набагато більше часу і можливостей у процесі навчання займатися науковою роботою. Ми можемо собі дозволити викладання курсів для груп навіть 32 осіб, і такий індивідуальний підхід дає дуже добрі результати. КАУ - маленький університет, але за нами стоїть потужність усієї Академії: студенти КАУ можуть обирати собі наукових керівників і теми досліджень як мінімум серед усіх установ НАН України.

На сьогодні, для здійснення принципу «освіта через науку», ми маємо такі освітньонаукові підрозділи (кафедри):

- кафедра біофізики і молекулярної фізіології (базується в Інституті фізіології ім. О.О. Богомольця НАН України);

- кафедра молекулярної біології (Інститут молекулярної біології і генетики НАН України);

- кафедра фундаментальних проблем загальної та прикладної фізики (Інститут фізики НАН України);

- кафедра теоретичної та математичної фізики (Інститут теоретичної фізики ім. М.М. Боголюбова НАН України);

- кафедра прикладної фізики та наноматеріалів (Інститут металофізики ім. Г.В. Курдюмова НАН України);

• кафедра математики (Інститут математики НАН України);

- кафедра теоретичної кібернетики та методів оптимального управління (Інститут кібернетики ім. В.М. Глушкова НАН України);

- кафедра прикладної фізики та матеріалознавства (Інститут електрозварювання ім. Є.О. Патона НАН України);

- кафедра хімії (Інститут фізичної хімії ім. Л.В. Писаржевського).

Процес становлення кафедр поки що триває: деякі з них уже розгорнули повноцінну діяльність, а деякі ще перебувають на стадії форму- вання. Звісно, найбільші проблеми виникають у зв'язку з організацією фінансування.

Принцип «наука через освіту» - це, власне, те нове, що ми привносимо в КАУ порівняно з КВ МФТІ, це наука, яка робиться чи безпосередньо студентами, чи внаслідок тісної з ними взаємодії. Розвиток наукової складової я проілюструю на прикладі Центру квантових матеріалів та технологій КАУ, що є близьким до тематики моїх власних досліджень. На сьогодні Центр виконує такі проєкти, в яких задіяні студенти:

- проєкт «Квантові матеріали для квантових технологій» в рамках нової фундаментальної теми НАН України на 2021-2025 рр.;

- проєкт МОН України «Нечіткі безперервні квантові вимірювання надпровідних кубітів» на 2021-2022 pp.;

- проєкт НФДУ «Багатозонність електронних станів: фізика та застосування» за програмою «Підтримка досліджень провідних та молодих учених» на 2020-2022 pp.;

- проєкт «The Ukrainian-German Excellence Center for Topological Matter» (UKRATOP) Міністерства освіти і науки Німеччини (BMBF) на 2018-2022 pp. 3 фінансуванням близько 1 млн євро, на початок 2021 р. стажування за цим проєктом від КАУ пройшли 7 магістрів, 1 аспірант та 2 докторанти;

- проєкт «German-Ukrainian Center for Quantum Materials» (GU-Qumat) також за програмою BMBF на 2021-2022 pp.

Загалом з німецькими колегами у нас дуже плідно розвивається співпраця, і як їі розширення й поглиблення ми бачимо створення в Києві Німецько-українського центру досліджень квантових матеріалів. Також ми розвиваємо Центр дослідження даних, що має об'єднати використання методів машинного навчання у математиці, фізиці, матеріалознавстві, науках про життя та інноваційній економіці.

Окремо хочу зупинитися на Інноваційному центрі КАУ та проєкті Academ-City, двигуном якого є Олександра Антонюк. Цей проєкт також розробляється у співпраці з німецькими науковцями і має на меті створення в Києві на 
базі академічних інститутів Академмістечка сучасного наукового парку за прикладом наукового парку Berlin-Adlershof. Особливість проєкту полягає в поєднанні в одному місці трьох складових - науки, освіти та інновацій.

Ці складові притаманні і нашому баченню структури КАУ. Досі КВ МФТІ, ФТННЦ та КАУ функціонували як заклад вищої дуальної освіти для НАН України. Подальший розвиток КАУ ми бачимо в посиленні як наукової, так і інноваційної складових. I якщо для першої необхідним є розвиток сталого міжнародного співробітництва (системи стажувань, подвійних дипломів), то для другої - залучення наукомістких компаній та підтримка студентських стартапів.
Ми розглядаємо КАУ не як ізольований академічний університет, а як місток між Академією та іншими університетами. I до наукових та інноваційних проєктів ми досить успішно залучаємо студентів не лише КАУ, а й інших університетів, як магістрів, так і бакалаврів. До власної ж магістратури ми наразі приймаємо випускників бакалавратів інших університетів, однак досвід останніх кількох років вже свідчить про те, що свій бакалаврат КАУ дуже потрібен.

Детальніше про те, що я не встиг розповісти в короткому виступі, особливо про низку наших заходів для учнів та вчителів, можна прочитати на сайті kau.org.ua.

Дякую за увагу! 